原著

$\mathrm{KrF}$ エキシマレーザーの基礎的研究

一第 2 報 ラット大腿骨骨切創の治癒過程一

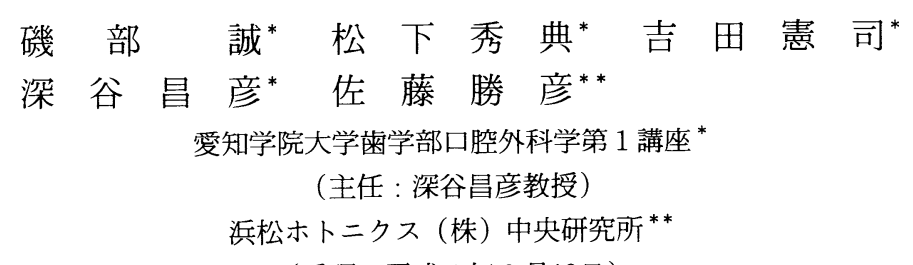

（受理: 平成 4 年 2 月 13 日）

\title{
Fundamental Study of KrF Excimer Laser
}

-The Second Report: The Healing Process of Incision in Rat's Femur-

\author{
Makoto ISOBE* ${ }^{*}$ Hidenori MATSUSHITA*, Kenji YOSHIDA*, \\ Masahiko FUKAYA* and Katsuhiko SATO** \\ The First Department of Oral and Maxillofacial Surgery, \\ School of Dentistry, Aichi-Gakuin University ${ }^{*}$
}

(Chief: Prof. Masahiko FUKAYA)

Hamamatsu Photonics K. K. Central Research

Laboratory Hamakita Research Park ${ }^{* *}$

(Accepted for Publication: February 13, 1992)

\begin{abstract}
A pulsed ultraviolet excimer laser has been investigated as a cutting-ablating tool for bone surgery. The special feature of the $\mathrm{KrF}$ excimer laser is that it cuts bone tissue without thermal damage. In our earlier report, we determined the best frequency for healing of femur wound. In the present study, femurs were examined over a long period. The laser was used at pulse energy : $50 \mathrm{~mJ}$, beam spot: $0.015 \mathrm{~cm}^{2}$, pulse width: $15 \mathrm{~ns}$, peak power : $3.3 \mathrm{MW}$, energy density : $33.3 \mathrm{~J} / \mathrm{cm}^{2}$, incision speed : $4 \mathrm{~mm} / \mathrm{min}$, irradiation time : $30 \mathrm{~s}$, and frequency : $20 \mathrm{~Hz}$. The femurs were examined histopathologically just after the operation, and at $1,2,4,8,12$, and 48 weeks after the operation.

In the case of femurs examined at the postoperative 48th week, there was remaining thermal damage around the cortical bone, and the new bone did not connect with the cortical bone.
\end{abstract}

Key words = Excimer Laser : Rat's Femur : Healing Process of Bone Incision キーワード=エキシマレーザー : ラット大腿骨 : 骨創鹪治癋 


\section{緒言}

近年，エキシマレーザーは紫外線領域でパルス発振す る硬組織切開が可能なレーザー裝置として注目されつつ ある ${ }^{1}$ 。その特性は $\mathrm{CO}_{2}$ レーザーや $\mathrm{Nd}: \mathrm{YAG} レ ー$ ザーと異なり，生体硬組織に対して熱的影響をほとんど 与えるととなしに組織の切開が可能であるというととが いわれてきだ1-4)。

しかし，本レーザーを用い著者がラット大腿骨に作成 した骨切創は, 病理組織学的に照射後 4 週を経過しても， 断端皮質骨に熱変性層力残存し，母骨之新生骨の完全癒 合は認められなかっだ5。

今回はこの熱変性層と母骨および新生骨の痹合過程を 長期にわたって観察するため, 前報の結果をるまえ，皮 質骨を確実に貫通し比較的治瘜傾向の良い, 繰り返し周 波数 $20 \mathrm{~Hz}$ の条件下で骨切創を作成した。観察方法は病 理組織学的観察を中心に，肉眼所見との比較検討を行っ た。

\section{実験方法}

\section{1. 実験動物}

ウイスター系雄性ラット（体重180-200g）35匹を実験 に供した。

2. 照射条件および照射方法

レーザー裝置は波長 $248 \mathrm{~nm}$ の $\mathrm{KrF}$ 浜松ホトニクス 社製エキシマレーザーC $3470 を$ 用いた。

照射条件：照射条件はパルスエネルギー：50mJ，ビー ムスポット : $0.015 \mathrm{~cm}^{2}$, パルス幅 : $15 \mathrm{~ns}$ ，ピークパワー $3.3 \mathrm{MW}$, エネルギー密度 : $33.3 \mathrm{~J} / \mathrm{cm}^{2}$, 切開速度 : 4 $\mathrm{mm} / \mathrm{min}$, 照射時間 $30 \mathrm{~s}$, 繰り返し周波数 $20 \mathrm{~Hz}$ とし た。

照射方法 : ペントバルビタール腹腔内麻酔 ( $45 \mathrm{mg}$ / $\mathrm{kg}$ ）下に大腿骨を露出し，可及的に外骨膜を剥離した のちに，専用の移動裝置に固定，大腿骨頭より $15 \mathrm{~mm}$ 未梢側の部分に長軸方向に対して垂直に長さ $2 \mathrm{~mm}$ の 骨切創を作成し，筋層および皮膚縫合を行った。

\section{3. 試料作成法および観察方法}

照射直後，1，2，4，8，12，48週後にそれぞれ頸部よ り鵍血，屠殺後大腿骨を摘出し，創部を肉眼的に観察し た後, 通法によるへマトキシリン・エオシシン重染色標本 を作製し，病理組織学的観察を行った。

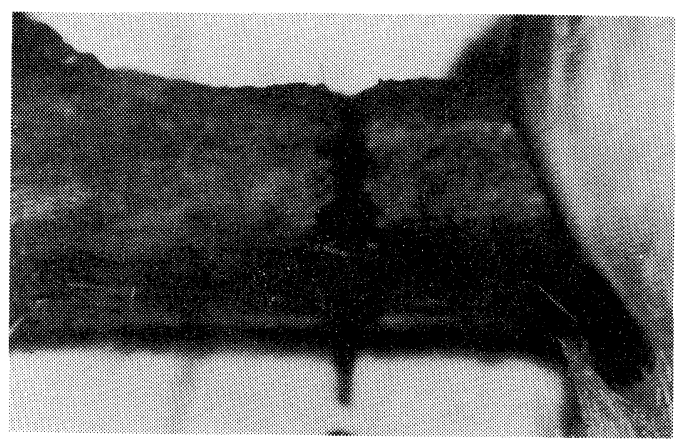

図 1 照射直後肉眼所見

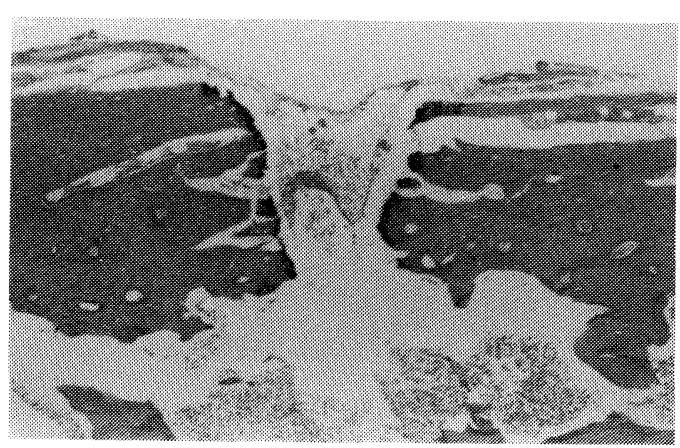

図 2 照射直後病理組織学所見

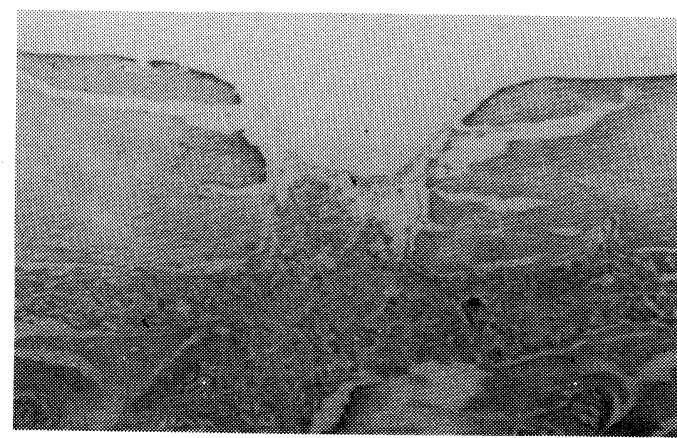

図 3 照射後 1 週病理組織学所見

\section{結 果}

\section{1. 照射直後}

肉眼的には切開面は鋸苗状を呈していた（図 1)。病 理組織学的には切創周囲皮質骨全体にわたる变性層が存 在し，切創部には赤血球か認められた（図 2)。

2. 1 週

肉眼的所見として，創部は暗赤色の凝血塊のような状 態で骨組織は認められなかった。病理組織学的には，創 面周囲の骨には変性層がみられ, 創部の一部に肉芽組織 


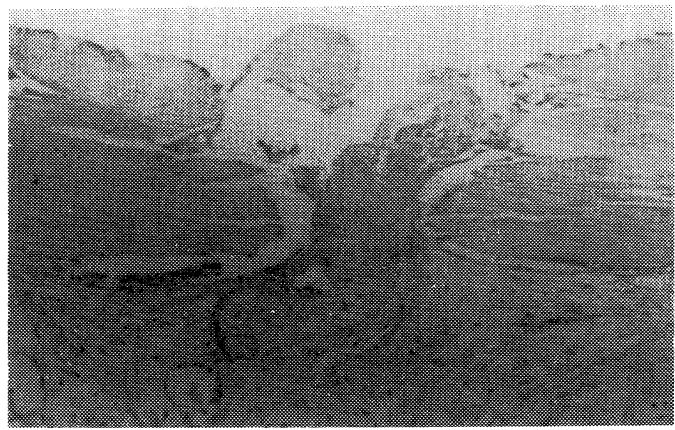

図 4 照射後 2 週病理組織学所見

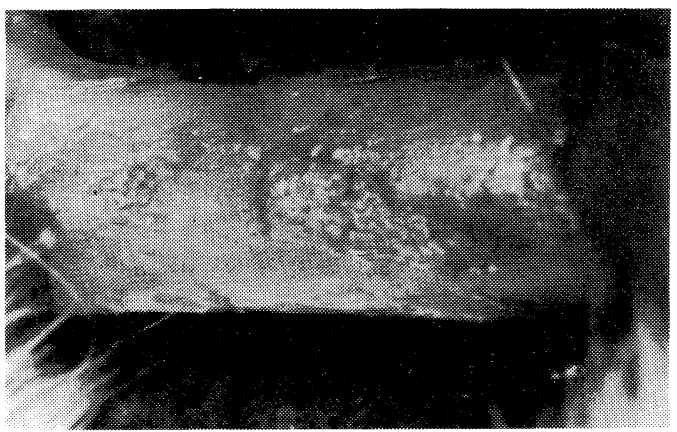

図 5 照射後 4 週肉眼所見

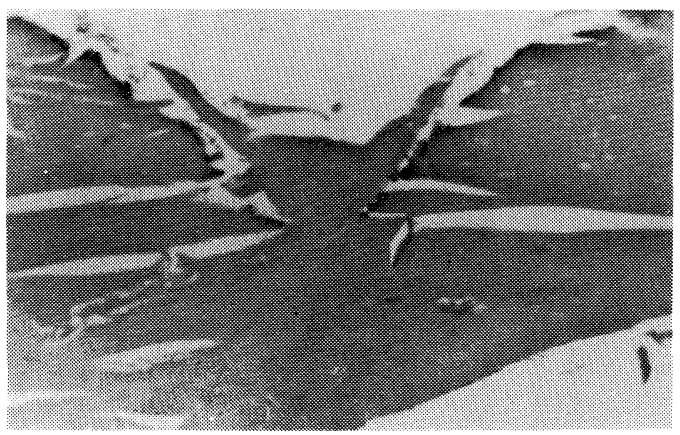

図 6 照射後 4 週病理組織学所見

がみられた（図 3)。

3. 2 週

2 週を経過しても肉眼的, 病理組織学的に 1 週との所 見の相異は認められなかった（図 4)。

4. 4 週

肉眼的には治瘾が促進され，切創部には線条の痕跡を 残した（図 5)。病理組織学的には内骨膜由来の骨化が 恋められたが，母骨周井の変性層は残存した（図 6)

5. 8 週

肉眼所見は線条痕跡は依然存在するものの 4 週に比べ

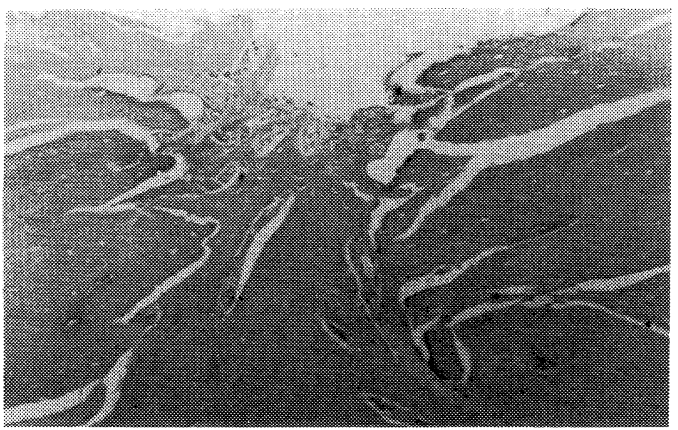

図 7 照射後 8 週病理組織学所見

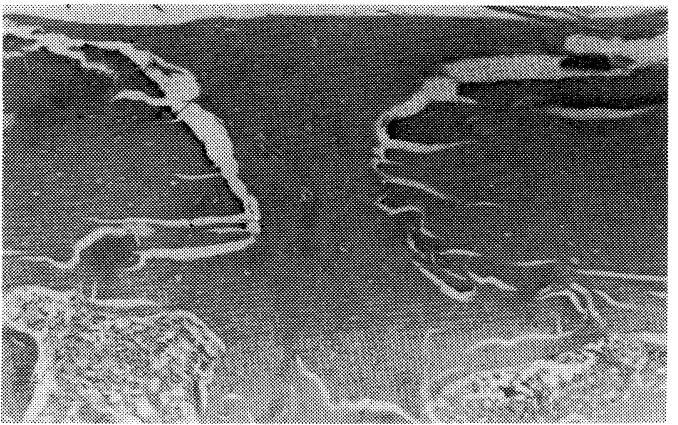

図 8 照射後12週病理組織学所見

て不明瞭となってきた。病理組織学的所見は, 切創部は 母骨とほぼ同等まで石灰化が進んだ内骨膜由来の骨組織 で満たされている。切創周囲の変性層は依然として残存 しており, 同部に破骨細胞, 骨芽細胞などの骨改造細胞 の存在は確認されなかった（図 7)。

6. 12 週

肉眼所見は周囲骨との区別がつきにくくなり，ほぼ治 癒の状態が確認された。病理組織学的所見では，切創部 は内骨膜由来の新生骨が主となり補填されているが，母 骨切創面の変性層の消失および，母骨と新生骨の癒合は 認められなかった。また，新生骨の一部に外骨膜との癒 合か認められた（図 8)。

\section{48 週}

肉眼的に骨切創部の痕跡は完全に消失, 治瘾している が（図 9), 病理組織学的には，切創部は内外骨膜由来 の新生骨で補填されているものの，乙の時期においても やはり母骨と新生骨の完全癒合がみられず，一部に変性 層か残存していた（図10）。

\section{考察}

エキシマレーザーは，紫外線領域でパルス発振し，そ 


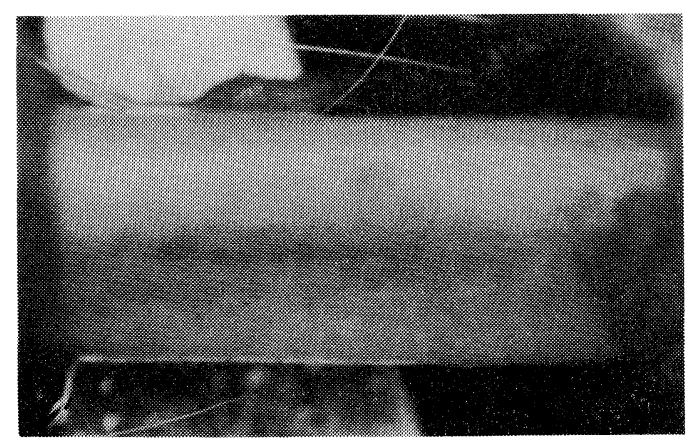

図 9 照射後 48 週肉眼所見

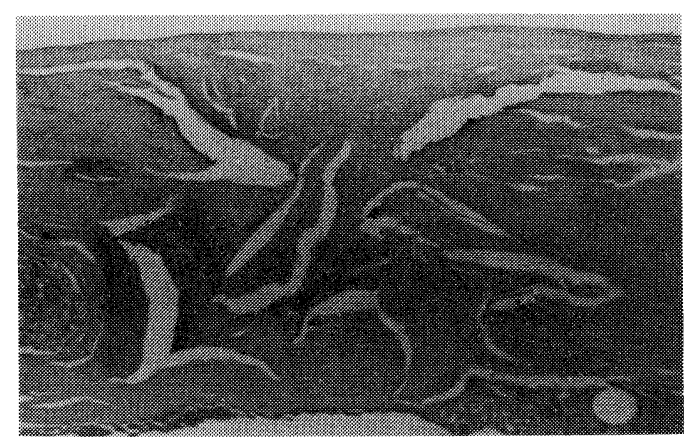

図 10 照射後48週病理組織学所見

の切開機序は生体を構成する分子間の結合を破壊，切断 する光化学反応であり ${ }^{2)}$, 理論的には熱影響なく切開で きるレーザー裝置である。低エネルギーで時間を十分に かけた切開では，組織に熱影響による損傷をほとんど与 えない。しかし，実際に硬組織切開に応用する場合，切 開効率を考えると, 高エネルギーが要求され，ピークパ ワーを増大するが，繰り返し周波数を大きくする必要が ある1)。しかし, てれらの条件の変化により, 周囲組織 への熱影響による損傷も比例して大きくなる。熱の発生 は特に繰り返し周波数が大きく関係し，レーザー照射時 における熱の蓄積に影響する。すなわち, 発生熱と熱拡 散速度によって決められる。発生熱は試料に吸収された エネルギーが，穿孔や螢光に費やされた残りのエネルギー である。レーザー照射により発生した熱エネルギーは, 時間とともに周辺組織へ拡散するが，パルス周期が短く なる.と十分な熱拡散が行われずに温度が上昇する。乙の ためパルス周期が短くなると照射部の温度が高くなり熱 変性層を生ずる ${ }^{6)}$ 。

本検索の条件下で作成された骨切創周囲の変性層は, 病理組織学的に骨切創作成後48週を経過しても, その消 失が確認されなかった。このてとは, 変性層部が完全に 吸収されるととなく病理組織学的に無細胞の状態を48週
経過時まで呈していたととより，破骨細胞，骨芽細胞な どの骨改造細胞の活動が抑制されている可能性が推測さ れ，照射時の熱影響が大きく関与して母骨と新生骨の完 全な癒合が得られないものと思われる。一方，落合 ${ }^{2}$ は エキシマレーザーにより切断された大腿骨断端の壊死組 織などは, 術後16週にてほぼ吸収され, 断端間をブリッ ジングしていたと報告している。この結果との相異は, われわれが大腿皮質骨の一部を切開し, 治癒経過を観察 したのに対して, 落合は大腿骨を完全に切断したてと, われわれの研究に比べ落合の研究では, 壊死組織が量的 に非常に大量であったてと, また, 壊死組織が線維性組 織, 肉芽組織, 骨膜などに直接接していたてとなどが考 えられる。

48週経過時点で肉眼的には完全治癒を思わせ, 病理組 織学的にも外骨膜部での接合が確認され, 骨癒合として 臨床的強度には問題ないものと考えるが, 照射部の母骨 辺縁に残存した熱変性層が生体にどのような影響をもた らすかが今後の課題となると考えられる。

\section{結 論}

本照射条件下において，エキシマレーザー照射により 得られたラット大腿骨骨切創には, 熱変性層が存在し, その変性層は照射後48週を経過しても存在した。また， 母骨と新生骨の完全なる癒合は照射後 48 週を経過しても 得られなかった。

稿を終えるにあたり，実験に協力していただいた浜松 ホトニクス (株) 中央研究所, 藤坂伸一, 垣内岳春両氏 に感謝致します。

\section{文献}

1) 佐藤勝彦, 山本 肇：エキシマレーザーによる骨手 術. O. plus E. 109 : 94-100, 1988.

2) 落合 聡：ラット舌と大腿骨のエキシマレーザー創 の治癒過程の病理組織学的研究一特に生体組織切開 能について一。病誌, 57 (4):631-651, 1990.

3) R. Srinivasan and W. J. Leigh: Ablutive Photodecomposion: Action of Far-Ultra violet (193nm) Laser Radiation on Poly (ethylene terephthalate) Films. J. Am. Chem. Soc. 104:6784-6785, 1982.

4) L. Yow. J. Stuart Nelson and M. W. Berns: Ablation of Bone and Polymethyimetacrylate by an $\mathrm{XeCl}$ (308nm) Excimer Laser. Lasers in Surgery and Medicine. $9: 141-147,1989$.

5) 磯部誠, 吉田憲司, 石原 朗, 松下秀典, 深谷昌彦, 佐藤勝彦：エキシマレーザ一の照射による基礎的研 究. 日本レーザー雨学研究会誌, 2(1)：30-31, 1991.

6) 岸田克彦, 久保宇市：骨組織へのエキシマレーザー の熱作用. 日本レーザ一医学会誌, 12 (1)：42-43, 1991. 